\title{
Learning based on Virtual Class using combination of Second Life and Learning Managment System
}

\author{
Firli Irhamni ${ }^{1}$, Indah Agustien Siradjuddin ${ }^{1}$, Arik Kurniawati ${ }^{1}$, Ari Kusumaningsih ${ }^{1}$, \\ and Rima Triwahyuningrum ${ }^{1}$
}

\begin{abstract}
Learning is the most important aspect for increasing the quality of youth generation in a nation. Therefore many learning methods are developed in order to make the youth more qualified. Virtual class based on the second life learning method is proposed in this research. The objective of this learning method is to make learning process more organize and interesting for the youth. There are four stages to build virtual class based on the second life. First, create course material for the learning process. Second, make the virtual class scenario, i.e. student registration, evaluation, and the graduation. Third, design the avatar and the classroom hence the student can get in touch with each other and understand the course material easily. Fourth, build the virtual class based on second life and the scenarios. In this research second life is combined with moodle for learning hence the learning process more interesting and more understandable to the youth.
\end{abstract}

Keywords-learning, second life, virtual class, moodle.

\section{INTRODUCTION}

L earning based on virtual class is an alternative learning method for student to understand their learning topics. In the conventional learning method, the students and teacher must be in the same room, and the teacher explains about the topic to the students. The conventional learning process will have difficulty since this process need the presence of the teacher. The other disadvantage of this conventional process is lack of illustration of the topics.

The alternative method uses virtual class for the learning process is proposed for an alternative learning method in this research because of the advantages. There are five advantages of virtual class for the learning process, i.e., distance learning, simple, interactive, individual, social [1].

The first advantage of the virtual class for learning is the capability of distance learning. It means that, with virtual class, the students and the teacher should not in the same room, the virtual class is accessible for everyone and from everywhere, the students do not have to travel to certain place to study the topics, and etc. The second advantage is simple. To access virtual class, it is only need common ICT equipment such as internet connection, computer, and a headset. To access the virtual class the students should learn also the skill of entering and using virtual class in second life.

The third advantage of using the virtual class for the learning process is interactive, engaging, social, and playful. The student is able to discuss the topic using the chat facility, the virtual class provide games and interactive objects, the student is able to go to interesting virtual places such as museum, white house, eifel tower, and etc. The Fourth advantage is the fact that the students are able to access the virtual class in their

${ }^{1}$ Firli Irhamni, Indah Agustien Siradjuddin, Arik Kurniawati, Ari Kusumaningsih, and Rima Triwahyuningrum are with Departement of Informatics Engineering, Faculty of Engineering, Universitas Trunojoyo Madura, Bangkalan, Indonesia. E-mail: firli@trunojoyo.ac.id;indah.agustien@if.trunojoyo.ac.id;ayyiik@yahoo .com;arikusuma@if.trunojoyo.ac.id;rimatw@yahoo.co.id. mobiles, therefore the virtual class is individual. The nerds student can study at their own room, the auditiv students are able to learn while listening their playlist, and etc. The final advantage is social, the participants of the topics are engaged with the virtual class, hence they can interact each other.

\section{METHOD}

Computer with Graphic and high internet connectivity supported is required to implement learning based on virtual class. Certain softwares are also needed in order to use this virtual class, they are Moodle, Second Live Viewer, and Sloodle. There are three main stages to create learning based on virtual class, i.e. joining second life, setting up and preparing the moodle and sloodle.

Second life is virtual environment which there are avatars that represent the user, 3D building with its environment such as water, land, furniture, house, and etc. The avatar can visit another place in second life, communicate with another avatar, do the transaction process, or another social activity. To join the second life environment, id user must be created first then install the second life viewer as shown in Fig 1.

a. To set up and prepare the moodle, this research use the moodle version 9.1 since this moodle is able to integrate with last version of sloodle. Seven steps are needed to install and prepare the moodle, i.e.:

b. Download required version of moodle at http://download.moodle.org

c. Download XAMP or WAMP server to access the created virtual class

d. Extract the moodle into certain folder (the folder for the localhost), which is ...xampplhtdocs. Run the xamp server, and access the temporaly downloaded moodle by opening the browser and type the url http://localhost.

e. Create folder "moodledata" at .. Ixampp. Change the access right of the folder with Full Control access

f. Edit file config.php which is at the directory ..xxampplhtdocs\moodlel with this following changing

i. $\$$ CFG->dbtype = 'mysql'; // mysql or postgres 7 (for now) 


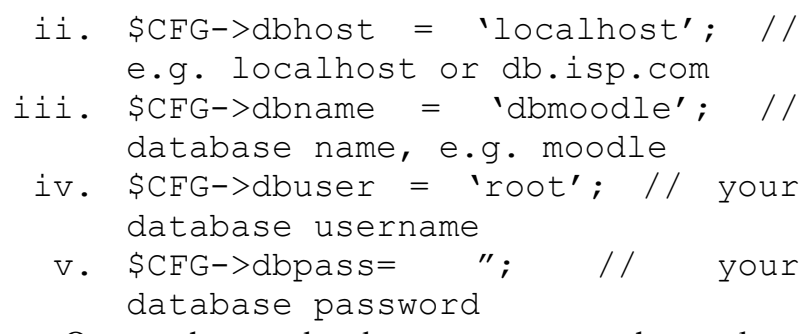

g. Open the web browser, type the url : http://localhost/phpmyadmin/, in the "Create new Database" menu, type 'dbmoodle' (as in the config.php file) and click "create" button

h. Type the url at the web browser : http://localhost/moodle/ to start the installation process

Since the moodle file must be created or installed at the public internet, then this research create the public website, and be able accessed on www.trunojoyolearning.com/virtualLearning

The last step for creating the learning based on virtual class is creating and preparing the sloodle. There are two parts of sloodle software, i.e. server side and moodle intregated. At the server side, the sloodle can be downloaded slisapps.sjsu.edu/sl/index.php/Download_Soodle and this sloodle software is installed in the moodle. The second part of sloodle is provided by the second life and can be downloaded

at http://maps.secondlife.com/secondlife/English\%20Villag e/141/126/22 . Second life viewer is required to access this part of sloodle.

There are six steps for installing the sloodle software, i.e.:

a. Back up installed moodle before installing sloodle software

b. Access the installed moodle hence the moodle can be intregated with the sloodle using one of the following steps:

i. use FTP if the moodle is hosted in the public website

ii. use File Manager if the moodle is installed in the local computer

iii. use Webhost's tools if the moodle is web based version

c. Unzip the downloaded sloodle software

d. Copy sloodle folder into mod folder which is in the moodle folder

e. Access the moodle as the administrator which is at the administrator page. In this research, the administrator page can be accessed at the http://trunojoyolearning.com/virtualLearning/admin meanwhile if the moodle is installed at the local server, then the administrator page can be accessed at the http://localhost/moodle/admin

f. Finish the sloodle installation process, if the process is succeded then there will be a message 'tables have been set up correctly' as shown in Fig. 2.

Following are the steps to integrate sloodle with secondlife (Sloodle-in world tools):

a. Open the secondlife viewer

b. Avatar or user should enter the secondlife world at http://maps.secondlife.com/secondlife/English\%20V illage/141/126/22 (English Village Sandbox) with their id that are created before. The objective of avatar entering the english village is to get the sloodle-in world tools. This process is depicted in Fig. 3.

c. Choose the Sloodle Set Version 1.2 as in Fig. 4

d. Press ' 1 ' button at the dialog menu the will show after choosing the sloodle set

e. Press 'keep' button at the showed dialog menu, and then this process make the sloodle set will be in the inventory

The last step to create learning based on virtual class is creating the environment (such as building, class room, water, and etc) of the second life using the tools from the inventory and integrate this second life the installed moodle and sloodle.

Many features that are provided by the second life for learning system, i.e.:

a. Presenter is presentation media which can combine images, video, and web pages.

b. prim drop is transaction log in the moodle database so the avatar can collect their assignment

c. quiz chair is a quizes for avatar that are provided at the moodle and can be accessed in the secondlife

d. quiz pile on is a multiuser quizes

e. Toolbar Given is the information spot about blogging, classroom gestures, and etc.

f. Web Intercom is the chat media (live) between moodle chat and second life.

\section{RESULT AND DISCUSSION}

The content of learning based on the virtual class are provided by the SDIT Al Uswah, Surabaya. The objective of this collaboration is the created virtual class can be accessed and implemented in real learning method in the junior school. The learning fields of this learning content is 'frog surgical'. The choice of this field is proposed by the school, since according to the school rules, 'frog surgical' is forbidden because it is considered as tourchering the life creatures hence it is haram based on islam rules. Therefore, the learning based on the virtual class is very usefull for students, since the can do the learning process without facing the real object, which is frog.

Design of the 'frog surgical' can be seen in Fig. 5 as follows, Created virtual class with 'frog surgical' learning content can be accessed at http://TrunojoyoLearning.com/virtualLearning/. Content of this site is the moodle learning management system. From the moodle, the teacher is able to upload the lecture notes and quizzes, and this moodle is supported also by the chat room, hence all the users of the system can interact at each other.

This moodle also provide the users to enter the virtual class using the second life world in tools. The built environment of virtual class can be seen at Fig. 6 .

\section{CONCLUSION}

Learning based on virtual class is modern alternative for learning process. With this virtual class, student will have new experiences in virtual life. And also, with the help of virtual class, the limitation of learning process is reduced, such as forbidden activity of tourchering life objects, visiting important place that are far away from 
the student's location, interaction between student even students from another school in virtual life, and etc. Hopefully, with the alternative learning process the students will interested in the learning content and they will understand with the content.

\section{REFERENCES}

[1]. Jha, S.K, and Shahabadkar, P.K." Can Virtual Class Room Replace Real Class Room? A Case Study." The Journal of Enterprise Computing and Business Systems.2: 10-14. 1 Januari 2012

[2]. Wong G and Wong V, "Virtual Reality in Space Exploration", Technical Report, www.doc.ic.ac.uk, diakses 26 April 2013.

[3]. Satava RM, "Virtual Reality Surgical Simulator", Surgical Endoscopy Springer Journal, 7 :203-205, June 1993.

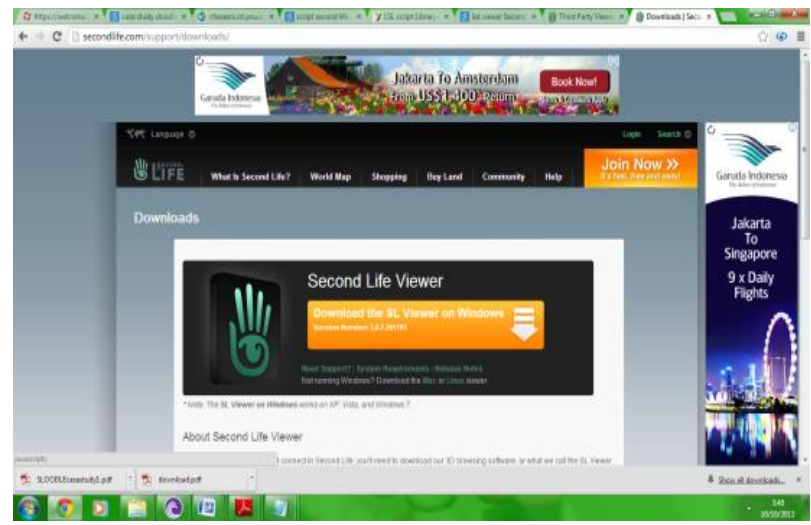

Figure 1. The Second life Viewer

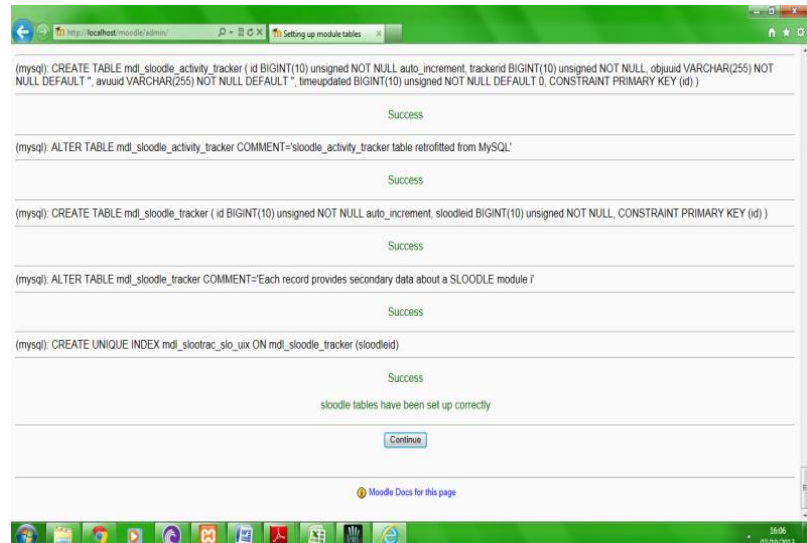

Figure 2. Success Installation of Sloodle at the Installed Moodle

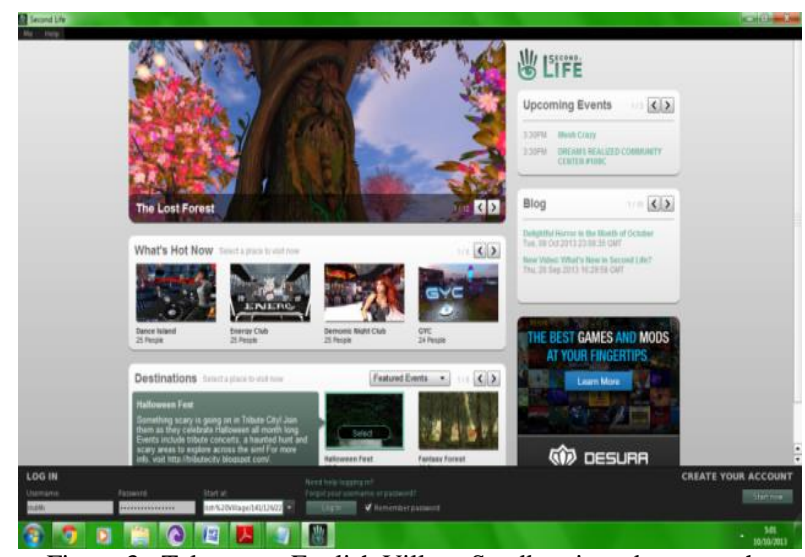

Figure 3. Teleport to English Village Sandbox in order to get the second life world of tools
[4]. Wong V, "Flight Simulation, an application of Virtual Reality", Technical Report, www.doc.ic.ac.uk, diakses tanggal 26 April 2013

[5]. Cathy, T.,Dave, W.,Luke, W.,Maggi, S.,Sheetal, K.,Terry P. 2009. Getting Started With Second Life.

[6]. Beveridge, M., \& Parkins, E.1987. Visual representation in analogical problem solving. Memory \& Cognition Journal, 15:230-237.

[7]. Linden lab, "second life education", reports document, Lindenresearch inc, 2011

[8]. Analisis Pemanfaatan E-learning Sebagai Media Pembelajaran Di Universitas Multimedia Nusantara http://eprints.binadarma.ac.id/76/1/B6\%20kkp.pdf

[9]. Sloodle.org

[10]. Callaghan M., McCusker K. , Lopez J., Introduction to SLOODLE, Serious Games and Virtual World Research Team, http://sgvwtv.ulster.ac.uk/.

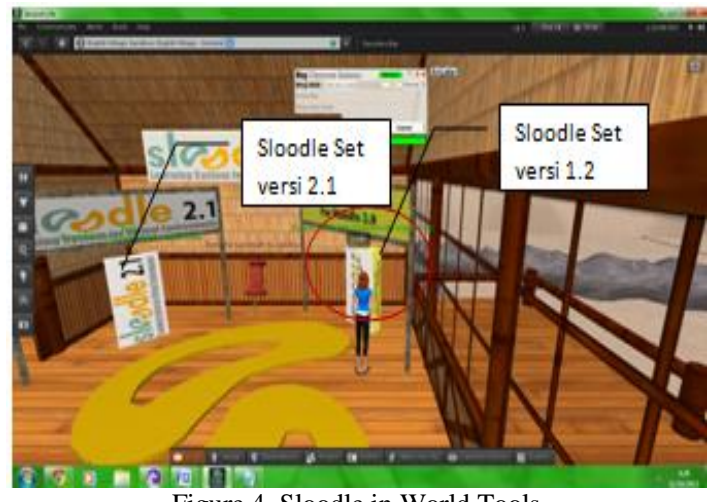

Figure 4. Sloodle in World Tools
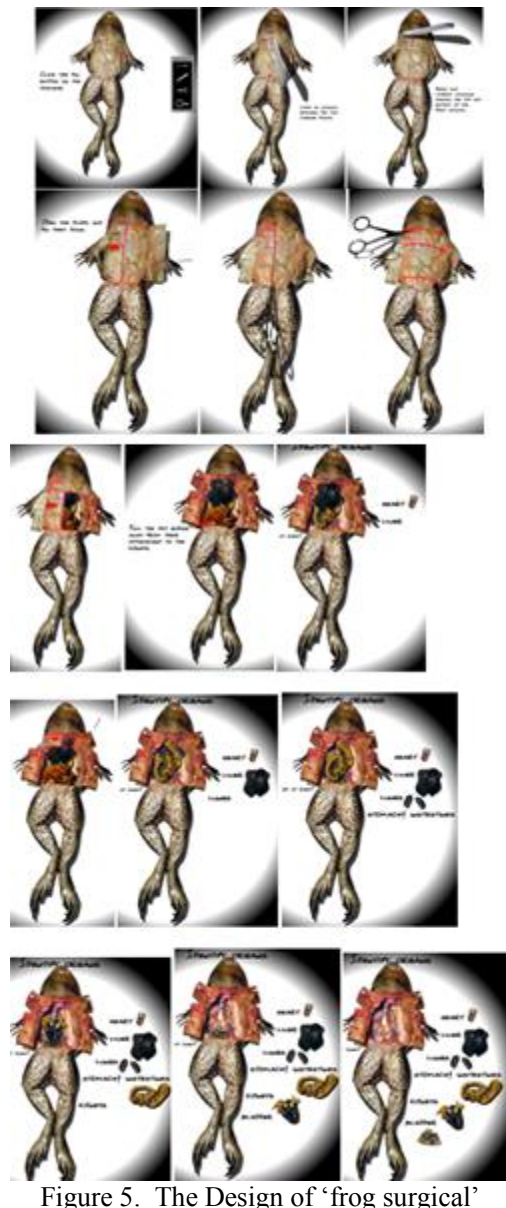


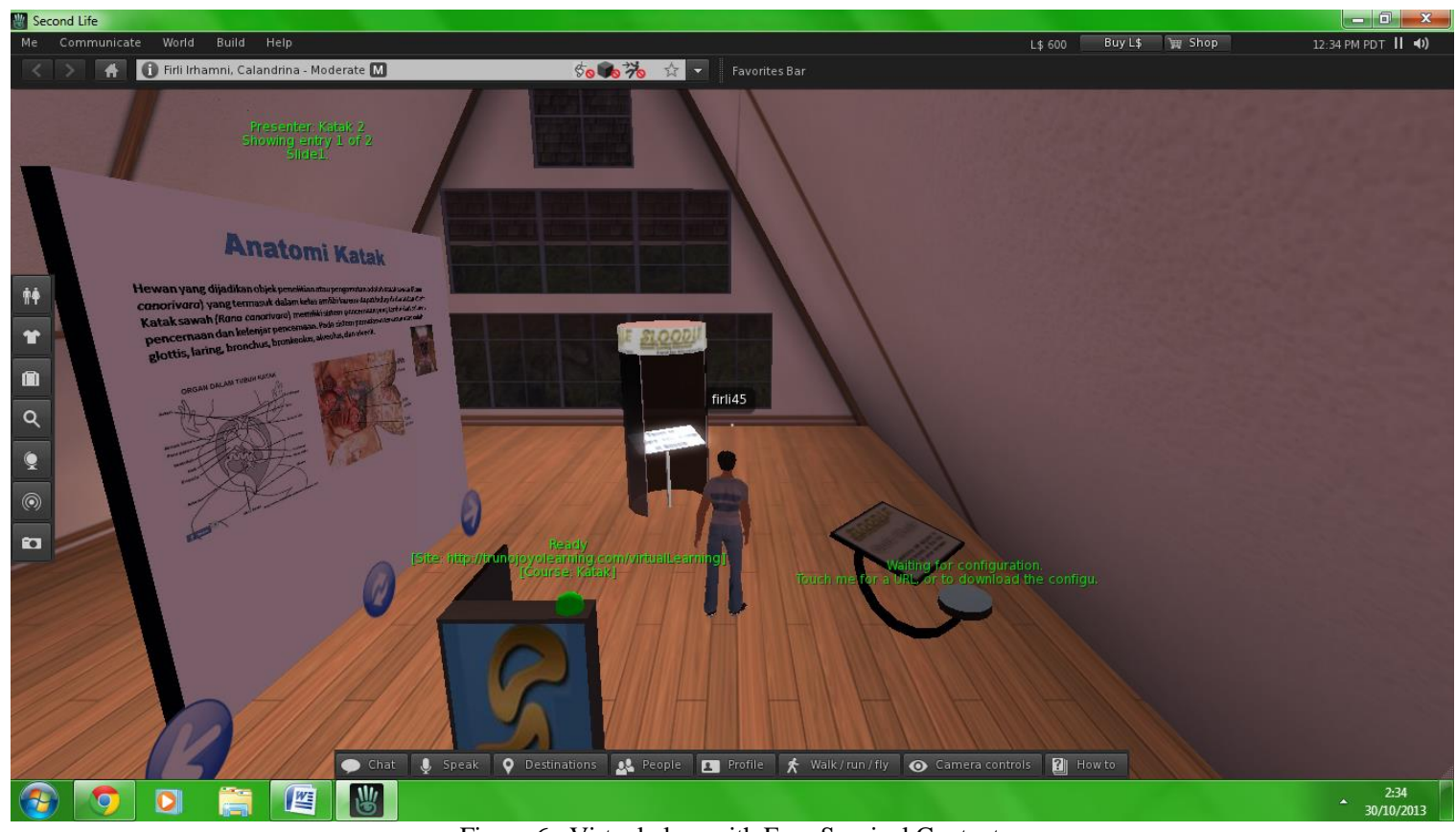

Figure 6. Virtual class with Frog Surgical Content 